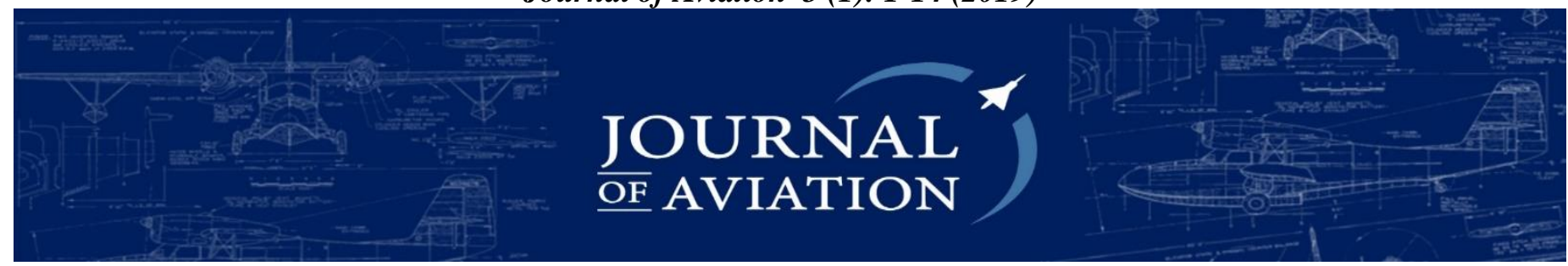

Received : 04.01.2019 \& Accepted : 21.02.2019 \& Published (online) : 14.03.2019

\title{
How Can an Ab-Initio Pilot Avert a Future Disaster: A Pedagogical Approach to Reduce The Likelihood of Future Failure
}

\author{
Bilal KILIÇ $*$ (D) , Semih SORAN ${ }^{1}$ \\ ${ }^{1}$ Faculty of Aviation and Aeronautical Sciences, Özyegin University, Istanbul, Turkey
}

\begin{abstract}
Safety is the primary concern of the civil aviation industry. This study aimed to explore the importance of learning from failures and improving the future performance of students by teaching this notion during an undergraduate course in the curriculum of the pilot training program. A questionnaire study was conducted with students of the pilot training program of the Faculty of Aviation and Aeronautical Science after the completion of a newly introduced elective undergraduate course, Aircraft Accident and Incident Investigation. Furthermore, for the first time, the contributing factors in accidents and incidents were analyzed and classified in an undergraduate pilot training program by using the Human Factors Classification and Analysis System (HFACS) as an analytical framework. The objective of the study was to find out if the "aspects of the accident investigation course at universities" were effective on "Technical Pilot Skills," "NonTechnical Pilot Skills" and "Program-Specific Outcomes." Correlation and Hierarchical regression analyses were conducted for this purpose. In the regression analysis, the variables were entered into the model and controlled. The results showed that the aspects of the accident investigation course improved technical and non-technical skills of the students, as well as their program-specific outcomes, and they were actively encouraged to extend their knowledge and skills beyond that required for the Airline Transport Pilot License (ATPL). It was revealed that this new undergraduate course does not only help learn the importance of non-technical skills (Crew Resource Management, Situational Awareness, etc.) but also develops and improves the technical abilities of ab-initio pilots.
\end{abstract}

Keywords: Accident investigation, organization, pilot training, Human Factors Analysis and Classification System (HFACS), air transportation

\section{Introduction}

The increase in global aviation drives the demand for new employees (pilots, cabin crew, technicians, etc.). According to the Airbus Global Market Forecast 2017-2036, the aviation industry will need 534,000 pilots over the next 20 years, and

* Corresponding Author: Dr.Öğr. Üyesi Bilal KILIC bilal.kilic@ozyegin.edu.tr the training of these employees plays a vital role regarding safety [1]. Furthermore, well-designed curricula and better undergraduate aviation programs are needed for the safe and successful training of novice pilots since the human factors

Citation : Kilic, B., Soran S. (2019). How can an ab-initio pilot avert a future disaster: A pedagogical approach to reduce the likelihood of future failure. Journal of Aviation, 3 (1), 1-14. DOI: 10.30518/jav.508336 
remain stubbornly high compared to the other contributing factors in accidents and incidents [2-4]. It is a well-known fact that airline companies and their conglomerates, airplane manufacturers, airport management employees, insurance companies and most importantly flight crews have an opportunity to learn from failures which have contributed to accidents and incidents [5]. With this consideration in mind, the objective of this study is to introduce a newly designed undergraduate course for aviation training programs and report the benefits of having this course and its contribution to civil aviation safety.

\subsection{Safety culture}

Safety has undergone tremendous developments over the past four decades [6]. Furthermore, safety has started to deal with the number of accidents, and detailed investigations have been made about the reasons for these accidents [7]. For this reason, safety has developed a proactive structure to prevent accidents. Safety is aviation's top priority, and organizations work continuously to increase safety standards. Improving safety is an ongoing activity where more needs to be done to attain zero accidents. Most of the accidents in aviation are still caused by lack of non-technical skills of pilots such as communication, leadership, teamwork, workload management, situational awareness and decision making $[8,9]$. We can evaluate all training activities conducted within this scope from a safety-related point of view. The experiences of accidents that have occurred in the past and related training will provide many benefits to the pilots in their decisionmaking processes. Whenever students are exposed to new experiences, they can make better decisions. These investigations of accidents help them decide in similar situations. In this context, the best way to teach them how to decide is to create judgment training models with constant learning. Learning has two principles, practice and feedback [10]. Safety and decision-making are concepts that are related to each other. For the teaching part, the presented decision is followed by an example. This is like situational training that provides decisional experiences to the student in a minimum actual flight hour. This is carried out through case studies, role-playing and simulations of decisions in situations faced by pilots, some of which resulted in accidents or incidents with a positive or negative outcome. The question is how can student pilots be taught judgment training in classrooms? A case study of scenarios of accidents or incidents may be useful since it allows verbal responses by everyone. Students could first work the problem individually and then in a small or big group. Another highly effective method for teaching judgment or safety is a flight simulator. Practical training may be provided in low-cost simulators as well as expensive ones. Students may study every abnormal scenario. Such scenarios should be based on true events, and the best sources for these practical training programs are the reports of past accidents and incidents.

\subsection{Learning from failures and accidents}

Learning from failures, accidents and incidents is the capability of an organization or individuals to obtain information and knowledge from past events and transfer these into measures and safety actions that will help avoid reoccurrences and improve safety in the related industry [11].

There have been a great number of studies on learning from failures, accidents and incidents in different areas in the last three decades [12]. These studies were mainly set out to benefit from the results of investigating accidents and incidents in different industries including healthcare, transportation, refinery and aviation [13-16]. Moura et al. published a study on learning from major accidents [17]. The goal of their study was to analyze major accidents and enable stakeholders to comprehend and learn from those accidents. An inspiring and promising study which comprehensively examined the nature of heavy vehicle crashes and the contributing factors associated with the crashes was carried out by Brodie et al. The descriptive study presented a way to increase the safety of heavy vehicle drivers by learning from fatal crash investigations by analyzing the contributing factors systematically [18].

Furthermore, it was reported that learning from past incidents and accidents enhances safety and enforces high safety standards in commercial aviation $[19,20]$. In-depth studies on learning from past accidents and incidents may be incorporated 
into the safety management systems of organizations, airlines and flight training institutions.

\subsection{Aircraft Accident Investigation and the Human Factor}

The human factor is of great importance for each of us from general aviation pilots to wide-body airliner pilots and any participants in the aviation industry [21, 22]. Based on the statistics, human factors have played an important role in aviation during the past three decades, and almost 75 percent of the contributing factors in accidents and incidents is the human factor [23]. Hence, we argue that a greater emphasis needs to be placed on human factors during the training of novice pilots.

Elwyn Edward developed a model which categorized the causes of all aviation accidents and helped understand the relationship between humans (Liveware) and aviation systems (Software, Hardware, Environment). Frank Hawkins modified this system by introducing the Liveware-Liveware relationship [24]. James Reason developed a model that has become the dominant paradigm for analyzing the causal factors of aviation accidents and incidents. There are four layers of human error in this safety metaphor, and each segment represents a barrier in the system that can prevent failures from occurring. This model is known as the Swiss cheese model [25].

However, there is a more sophisticated method, HFACS, which was developed by Dr. Scott Shappell and Dr. Doug Wiegmann. It is a comprehensive human error framework and based on the Swiss cheese model. Human error is described on four levels of failure, and each level of the structure comprises causal categories which help organizations identify and analyze the contributing factors proactively and prevent reoccurrence of similar events. Furthermore, this framework may be used to put in place preventive measures and alleviate potential human errors in aviation [26-28].

Since aviation is a multidisciplinary environment, there is an interaction between each organization such as meteorology offices, air traffic service units, airport ground services and operation of airlines. Therefore, each potential source for the contributing factors should be dealt with great care, and every possibility which might cause the same shortfalls should be considered. For clear understanding of the causal factors of the accidents analyzed during the course of the semester, an HFACS framework was used.

\subsection{Aircraft Accident \& Incident Investigation and Pilot Training}

Most universities around the world, such as Cranfield University [29], Embry-Riddle Aeronautical University [30], and University of Windsor [31] offer aircraft accident and incident investigation courses as an intensive short-term program. Such courses are mostly designed to be a step towards the postgraduate programs in Aircraft Accident Investigation.To the best of our knowledge, there has been no aviation faculty program which presents an aircraft accident investigation course on the undergraduate level up to know. The current classes at aviation faculties or world-renowned aviation authorities (e.g., NTSB, ICAO, FAA, etc.) provide only training for the applicants who want to become certified accident investigators [32]. The course contents are mainly designed to provide fundamental skills required of an accident investigator, investigation techniques and investigation simulation [33]. However, our brand-new course features basic and advanced aeronautical knowledge for ab-initio pilots and increases their situational awareness in addition to teaching them fundamental methods and investigation techniques in aircraft accident investigation.

\subsection{Aircraft Accident Investigation and Technical and Non-Technical Pilot Skills}

A certain set of skills is required to be a pilot. Pilot skills are divided into two categories: technical and non-technical [34]. For effective and safe flight operations, pilots need to have individual proficiency with technical skills, but this is not enough for a safe flight. In addition to proficient technical skills and knowledge such as an understanding of math and physics and specific technical knowledge and flying skills, they also need to develop good cognitive and social skills (non-technical skills) such as situation awareness, task management, co-operation, problem solving, team work, leadership and decision-making [35]. 
Such skills refer to pilots' behavior and attitude in the flight deck. They do not directly relate to aircraft control or system management. However, the nontechnical skills and technical skills of the flight crew may relate to each other. Like two sides of the same coin, non- technical skills cannot be separated from technical skills. Therefore, we need to consider these two together. For instance, a good decisionmaking (a non-technical skill) process is based on specific knowledge (a technical skill) and the ability to distinguish between correct and incorrect options. More specifically, a good meteorology knowledge would help pilots perceive their external environment and find an appropriate course of action under severe weather conditions. The more technical knowledge pilots have, the more accurately they can perceive what is in the flight deck and outside the airplane.

The United Flight 232 is a good example for the relationship between technical skills and nontechnical skills of the flight deck crew. It was a scheduled flight from Denver to Chicago on July 19, 1989 operated by two pilots. There was one more pilot, an instructor pilot of the United Airlines on board who was a passenger in the first-class section of the aircraft and helped the flight deck crew voluntarily. They experienced an uncontained engine failure at an altitude of 37.000 feet and the entire hydraulic system of the aircraft DC-10 that powered the airplane's flight controls was destroyed. With the help of massive knowledge of aircraft systems and keen perception skills, the flight deck crew and the off-duty instructor captain were able to perceive the nature of the emergency and make a sound decision for the correct solution. Finally, the flight crew was able to align the aircraft with the runway even if there were overarching influences such as stress, anxiety and severity of the emergency, as well as the severe difficulties in controlling the airplane. Unfortunately, the aircraft caught fire upon touchdown and tumbled. Out of 296 passengers, 185 survived [36]. Therefore, this accident is a profound illustration of how nontechnical skills and technical skills play an important role for resolving an emergency situation collectively. According to the 'Fatal Global Accident Review 2002-2011', three of the four primary causal factors to all accidents are related to non-technical skills as follows [37]:

1. Flight crew perception and decision-making

2. Flight crew situational awareness

3. Poor professional judgment or airmanship

The ICAO Document 9995 illustrated the importance of non-technical skills of a flight crew to increase overall safety in aviation [34]. It defined eight core competencies, and 5 out of these are associated with non-technical skills. These associated ones are;

1. Leadership and teamwork

2. Problem-solving and decision-making

3. Situation awareness

4. Workload management

5. Communication

In the light of the above, the institutions where the novice pilots attend should encourage them to recognize the importance of the non-technical aspects of crew performance in addition to technical skills during the course of their training. The significance of the relationship between human factors and aviation safety should be emphasized.

The success of pilot training is strongly influenced by the quality of flight training programs [38]. The curricula of each flight training organization, institution and university should foster situational awareness of error avoidance and promote prevention of accidents and incidents by providing a standardization of aviation training programs [39]. Courses based on the non-technical aspects of the flight crew should be included in the curricula of flight training programs.

\section{Methodology}

\subsection{Content and Outline of the Course}

The course is composed of 42 hours ( 3 hours a week) and 6 ECTS credits. One selected main topic is covered, and students are presented with a 1-hour long documentary of an accident per week (related to the subject of that week) (Table-1). After the documentary is watched, a brainstorming process is carried out with students to categorize and assess the causes that were established in the investigation report by using HFACS as an analytical framework. Furthermore, students are encouraged to define and criticize all contributing factors influential on the related aircraft accident and incident from a novice 
pilot point of view. During the course, in addition to technical knowledge (meteorology, flight-planning, communication, etc.), a great emphasis is placed on the importance of non-technical skills such as CRM, decision-making, situational awareness, etc.. For instance, in the third week, the Korean Air Flight 801 accident was analyzed. Firstly, a clear synopsis of the accident was introduced. After the documentary was watched, the students were encouraged to share their ideas about the probable causes from a novice pilot perspective. According to the conclusion of the investigation performed by NTSB, the likely contributing factors in this accident were the inadequate flight crew training of Korean Air, the flight crew's fatigue and communication breakdown between the cockpit crew. These reported factors contributing to the Korean Air Flight 801 accident were reviewed with the intention of avoiding any reoccurrence of these contributing factors rather than establish blame. The primary goal was to learn from failures and prevent repetition in the future.

The novice pilots were taught assertiveness, decision-making and CRM issues in the cockpit, as well as how to remain vigilant and perform pilot monitoring duties during a flight. It was mentioned that many errors, like decision-making errors or skill-based errors of the aforementioned accident, could have been prevented provided that the pilots had been aware of the environment and shown more assertiveness. Furthermore, the investigation techniques and procedures that were used for the Korean Air Flight 801 accident were described. Onsite investigation techniques, regulatory methods [40], initial safety actions and safety recommendations were illustrated. After the HFACS framework was introduced, the factors that contributed to the given accident and incident were analyzed by using this framework.

\subsection{Program Outcomes of the Course}

The mission of the Pilot Training Program that provides the AAI Course is to produce professional pilots who are vested with the necessary skills, competencies, theoretical foundation and practical experience to meet the needs of domestic and international airline organizations. Each course has a set of targeted learning outcomes determined by the instructor of the course, and these learning outcomes must support the faculty and specific program outcomes. Seven Program-Specific outcomes for graduated pilot are listed below:

a) Describe the professional attributes, requirements or certifications and planning applicable to aviation careers. *

b) Describe the principles of aircraft design, performance and operational characteristics, and the regulations related to the maintenance of aircraft and associated systems.

c) Evaluate aviation safety and the impact of human factors on safety. *

d) Discuss the impact of domestic and international aviation laws, regulations and labor issues on aviation operations. *

e) Explain the integration of airports, airspace and air traffic control in managing the National Airspace System.

f) Discuss the impact of meteorology and environmental issues on aviation operations. *

The program was developed and published between courses and aviation core topics. So, for the AAI Course, it is important to contribute to the outcomes that are mentioned in the Course Description Form. The outcomes that were selected by the instructor that was supposed to support students by the AAI course are a, c, d and f.

Based on the above, the following hypotheses were proposed:

H1. Accident Investigation Course in ab-initio pilot programs will positively affect the technical skills of pilots.

H2. Accident Investigation Course in ab-initio pilot programs will positively affect the nontechnical skills of pilots.

H3. Accident Investigation Course in ab-initio pilot programs has a positive correlation with Professional Flight (PF) Program-Specific Outcomes. 
Table 1. The content of the course

\begin{tabular}{|c|c|c|}
\hline Week & Theoretical Issue & Accident/Incident Documentary \\
\hline 1 & $\begin{array}{c}\text { Introduction of the Aircraft Accident } \\
\text { Investigation }\end{array}$ & British Airways Flight 38 \\
\hline 2 & $\begin{array}{l}\text { The fundamentals of the Aircraft } \\
\text { Accident Investigation }\end{array}$ & Birgen Air Flight 301 \\
\hline 3 & $\begin{array}{l}\text { Regulatory requirements of the } \\
\text { Aircraft Accident Investigation } \\
\text { ICAO Annex } 13\end{array}$ & Korean Air Flight 801 \\
\hline 4 & Introduction to the Human Factors & Helios Airways Flight 522 \\
\hline 5 & $\begin{array}{l}\text { The taxonomy of Contributing } \\
\text { Factors to the accidents and } \\
\text { incidents- Human Factors Analysis } \\
\text { and Classification System HFACS }\end{array}$ & Avianca Flight 052 \\
\hline 6 & Midterm-1 & \\
\hline 7 & $\begin{array}{l}\text { Mechanical failure and } \\
\text { teamwork }\end{array}$ & Qantas Flight 32 \\
\hline 8 & Environmentally-induced factors & Air France Flight 447 \\
\hline 9 & Weather-related phenomena & Air Florida 90 \\
\hline 10 & $\begin{array}{l}\text { Human perception and } \\
\text { situational awareness }\end{array}$ & Air France Flight 358 \\
\hline 11 & Midterm-2 & \\
\hline 12 & $\begin{array}{c}\text { The effect of the level of } \\
\text { automation }\end{array}$ & Colgan Air Flight 3407 \\
\hline 13 & $\begin{array}{l}\text { Threat and error management } \\
\text { (TEM) and crew resource } \\
\text { management }(\mathrm{CRM})\end{array}$ & Air Canada Flight 143 \\
\hline 14 & $\begin{array}{l}\text { Human error perspectives in } \\
\text { aviation } \\
\text { and semester summary }\end{array}$ & $\begin{array}{l}\text { A midair emergency over northern England. } \\
\text { The hero passenger who landed a plane (Cessna } \\
\text { 172) after his pilot fell unconscious mid-flight. }\end{array}$ \\
\hline
\end{tabular}




\subsection{Measures}

The questionnaire comprised four sections and 20 items: the aspects of the AAI course, contribution of the AAI course to the technical skills of pilots, contribution of AAI course to the nontechnical skills of pilots and contribution of the AAI course to specific outcomes ( $a, c, d$ and f) of the Pilot Training Program. The questionnaire was filled out among 80 ab-initio pilots in a Pilot Training Program of a university. The questionnaires were distributed to the students just after the course in 4 sections and gathered after 30 minutes. All the questionnaires were counted. The questionnaire may be found in Appendix-2.

\section{Findings and Analysis}

\subsection{Demographic Findings}

Pilot students from a university Pilot Training Program participated in this study. The ages of the participants ranged from 20 to 23 years old, while their flight training hours ranged from 75 to 175 hours. $85 \%$ of the participants were male, and $15 \%$ were female. The details of the of the sample are given below:

Table 2 . Age

\begin{tabular}{ccccc}
\hline & Frequency & Percent & $\begin{array}{c}\text { Valid } \\
\text { Percent }\end{array}$ & $\begin{array}{c}\text { Cum. } \\
\text { Percent }\end{array}$ \\
\hline 20 & 6 & 7,5 & 65 & 7,5 \\
21 & 30 & 37,5 & 100,0 & 45,0 \\
22 & 34 & 42,5 & 120 & 87,5 \\
23 & 10 & 12,5 & 12,5 & 100,0 \\
$\mathrm{~T}$ & 80 & 100,0 & 100,0 & \\
\hline
\end{tabular}

Table 3 . Gender

\begin{tabular}{ccccc}
\hline & Frequency & Percent & $\begin{array}{c}\text { Valid } \\
\text { Percent }\end{array}$ & $\begin{array}{c}\text { Cum. } \\
\text { Percent }\end{array}$ \\
\hline M & 68 & 85,0 & 85,0 & 85,0 \\
F & 12 & 15,0 & 15,0 & 15,0 \\
Total & 80 & 100,0 & 100,0 & \\
\hline
\end{tabular}

Table 4 . Flight Hours

\begin{tabular}{ccccc} 
& Frequency & Percent & $\begin{array}{c}\text { Valid } \\
\text { Percent }\end{array}$ & $\begin{array}{c}\text { Cum. } \\
\text { Percent }\end{array}$ \\
\hline $50-75$ & 3 & 3,8 & 3,8 & 3,8 \\
$76-100$ & 14 & 17,5 & 17,5 & 21,3 \\
$101-$ & 36 & 45,0 & 45,0 & 66,3 \\
125 & & & & \\
$126-$ & 24 & 30,0 & 30,0 & 96,3 \\
150 & & & & \\
$151-$ & 3 & 3,8 & 3,8 & 100,0 \\
175 & & & & \\
Total & 80 & 100,0 & 100,0 & \\
\hline & & & &
\end{tabular}

\subsection{Data analysis}

\subsubsection{Aspect of the course}

The aspects of the course were measured on a scale of 5 items. In the scale, the student pilots were asked to mark the extent to which they agreed with the statements related to their perception of the aspects of the course on a 5-point Likert-type Scale (1=Strongly Disagree, 5=Strongly Agree). High scores obtained from the scale indicate a high rate of agreement concerning the aspects of the course. The reliability coefficient (Cronbach's alpha) of the scale was found to be 0.914 .

\subsubsection{Technical Pilot Skills}

The effect of the course on Technical Pilot Skills was measured on a scale of 5 items. In the scale, the student pilots were asked to mark the extent to which they agreed with the statements related to their perception of the effects of the course to their Technical Pilot Skills on a 5-point Likert-type Scale (1=Strongly Disagree, 5=Strongly Agree). High scores obtained from the scale indicate a high rate of agreement concerning the student pilots' course perceptions about the effects of the course on their Technical Pilot Skills. The reliability coefficient (Cronbach's alpha) of the scale was found to be 0.929 .

\subsubsection{Non-Technical Pilot Skills}

The effect of the course on non-technical Pilot Skills was measured on a scale of 5 items. In the 
scale, the student pilots were asked to mark the extent to which they agreed with the statements related to their perception of the effects of the course on their Non-Technical Pilot Skills on a 5point Likert-type Scale (1=Strongly Disagree, 5=Strongly Agree). High scores obtained from the scale indicate a high rate of agreement concerning the student pilots' course perceptions regarding its effects on their Non-Technical Pilot Skills. The reliability coefficient (Cronbach's alpha) of the scale was found to be 0.937 .

\subsubsection{Program-Specific Outcomes}

The effects of the course on Professional Flight (PF) Program-Specific Outcomes were measured on a scale of 5 items. In the scale, the student pilots were asked to mark the extent to which they agreed with the statements related to their perceptions of the effects course on their PFPSO on a 5-point Likert-type Scale ( $1=$ Strongly Disagree, $5=$ Strongly Agree). High scores obtained from the scale indicated a high rate of agreement concerning the student pilots' course perceptions regarding its effects on their program-specific outcomes. The reliability coefficient (Cronbach's alpha) of the scale was found to be 0.938 .

\subsection{Variable Measures}

To ensure the validity and reliability of the variables of the study, explanatory factor analysis was conducted by the SPSS software.

The aspects of the course produced one factor in the analysis. The factor named "aspects of the course" explained $74.789 \%$ of the total variance. The resulting coefficient of the KMO Bartlett's Test of Sphericity was 0.887 .

The effect of the course on Technical Pilot Skills produced one factor in the analysis.

The factor named "Technical Pilot Skills" explained $78.949 \%$ of the total variance. The resulting coefficient of the KMO Bartlett's Test of Sphericity was 0.886 .

The effect of the course on Non-Technical Pilot Skills produced one factor in the analysis. The factor named "Non-Technical Pilot Skills" explained $79.946 \%$ of the total variance. The resulting coefficient of the KMO Bartlett's Test of Sphericity was 0.876 .

The effect of the course on Professional Flight (PF) Program-Specific Outcomes produced one factor in the analysis. The factor named "ProgramSpecific Outcomes" explained $80.870 \%$ of the total variance. The resulting coefficient of the KMO Bartlett's Test of Sphericity was 0.834 .

\subsection{Descriptive Results}

The highest scores were observed with the items "the course improved my aviation knowledge," "the course improved my situational awareness skills," "the course improved my aircraft and operational knowledge skills" and "the course improved my leadership and teamwork skills" (Table-5).

Table- 6 shows the factor means and standard deviations, as well as findings of the correlation analysis regarding the study's variables.

The mean score of the "aspects of the course" dimension was $3.82(\mathrm{sd}=1.04)$, the mean score of the "technical pilot skills" dimension was 4.10 $(\mathrm{sd}=0.80)$, the mean score of the "non-technical pilot skills" dimension was 4.07 ( $\mathrm{sd}=0.88)$, and the mean score of "program-specific outcomes" dimension was $3.84(\mathrm{sd}=1.20)$.

Based on the correlations between the dimensions, Technical Pilot Skills $(\mathrm{r}=0.733, \mathrm{p}$ $<0.01)$, Non-Technical Pilot Skills $(r=0.713, p$ $<0.01)$ and Program Specific Outcomes $(r=0.767$, $\mathrm{p}<0.01)$ were found to be significantly and positively correlated with the Aspects of the Course dimension. Besides, it was seen that the other factors were also in significant and positive relationships among themselves. 
Table 5 . Descriptive Statistics

\begin{tabular}{|c|c|c|c|c|c|}
\hline & $\mathrm{N}$ & Minimum & Maximum & Mean & $\begin{array}{c}\text { Std. } \\
\text { Deviation }\end{array}$ \\
\hline T3. The course improved my aviation knowledge. & 80 & 1,00 & 5,00 & 4,2000 & 0,94668 \\
\hline $\begin{array}{l}\text { N4. The course improved my situation awareness } \\
\text { skills }\end{array}$ & 80 & 2,00 & 5,00 & 4,1875 & 0,90139 \\
\hline $\begin{array}{l}\text { T5. The course improved my aircraft and operational } \\
\text { knowledge skills. }\end{array}$ & 80 & 2,00 & 5,00 & 4,1750 & 0,86822 \\
\hline $\begin{array}{l}\text { N2. The course improved my leadership and } \\
\text { teamwork skills }\end{array}$ & 80 & 2,00 & 5,00 & 4,1250 & 0,87692 \\
\hline $\begin{array}{l}\text { P1. Evaluate aviation safety and the impact of human } \\
\text { factors on safety. }\end{array}$ & 80 & 1,00 & 5,00 & 4,1125 & 0,98075 \\
\hline $\begin{array}{l}\text { N5. The course improved my workload management } \\
\text { skills }\end{array}$ & 80 & 2,00 & 5,00 & 4,1000 & 0,90847 \\
\hline $\begin{array}{l}\text { T4. The course improved my Aircraft Handling } \\
\text { skills. }\end{array}$ & 80 & 1,00 & 5,00 & 4,1000 & 0,93592 \\
\hline N1. The course improved my communication skills & 80 & 1,00 & 5,00 & 4,0750 & 0,96489 \\
\hline $\begin{array}{l}\text { N3. The course improved my problem solving \& } \\
\text { decision-making skills. }\end{array}$ & 80 & 2,00 & 5,00 & 4,0500 & 0,85536 \\
\hline C1. Assignments were reasonable and appropriate & 80 & 1,00 & 5,00 & 4,0375 & 1,02431 \\
\hline $\begin{array}{l}\text { T1. The course improved my application of } \\
\text { procedures skills. }\end{array}$ & 80 & 1,00 & 5,00 & 4,0125 & 1,06133 \\
\hline $\begin{array}{l}\text { P3. Discuss the impact of national and international } \\
\text { aviation law, regulations and labor issues on aviation } \\
\text { operations }\end{array}$ & 80 & 2,00 & 5,00 & 4,0000 & 0,98083 \\
\hline $\begin{array}{l}\text { P2. Discuss the impact of meteorology and } \\
\text { environmental issues on aviation operations. }\end{array}$ & 80 & 1,00 & 5,00 & 3,9875 & 1,03720 \\
\hline $\begin{array}{l}\text { P4. Explain the integration of airports, airspace, and } \\
\text { air traffic control in managing the National Airspace } \\
\text { System. }\end{array}$ & 80 & 1,00 & 5,00 & 3,9625 & 1,06073 \\
\hline $\begin{array}{l}\text { T2. The course improved my use of automatic flight } \\
\text { systems (AFS) skills. }\end{array}$ & 80 & 0,00 & 5,00 & 3,9125 & 1,10458 \\
\hline $\begin{array}{l}\text { C3. Syllabus accurately described course content and } \\
\text { objectives }\end{array}$ & 80 & 1,00 & 5,00 & 3,8625 & 1,17725 \\
\hline C2. Course pace and difficulty were appropriate & 80 & 1,00 & 5,00 & 3,8000 & 1,14073 \\
\hline $\begin{array}{l}\text { C5. How likely is it that you would recommend this } \\
\text { course to a friend? }\end{array}$ & 80 & 1,00 & 5,00 & 3,8000 & 1,27686 \\
\hline $\begin{array}{l}\text { P5. Describe the professional attributes, requirements } \\
\text { or certifications, and planning applicable to aviation } \\
\text { careers }\end{array}$ & 80 & 1,00 & 5,00 & 3,7875 & 1,22932 \\
\hline $\begin{array}{l}\text { C4. Exams and quizzes reflected course content and } \\
\text { objectives }\end{array}$ & 80 & 1,00 & 5,00 & 3,7750 & 150 \\
\hline
\end{tabular}


Table 6. Means, Standard Deviation and Correlations

\begin{tabular}{ccccccc}
\hline Variable & Mean & sd. & $\mathbf{1}$ & $\mathbf{2}$ & $\mathbf{3}$ & $\mathbf{4}$ \\
\hline $\begin{array}{c}\text { Aspect of the } \\
\text { course }\end{array}$ & 3.82 & 1,04 & $(0,914)$ & & \\
$\begin{array}{c}\text { Technical } \\
\text { Pilot Skills }\end{array}$ & 4.10 & 0,80 & $0,733^{* *}$ & $(0,929)$ & & \\
$\begin{array}{c}\text { Non- } \\
\text { Technical }\end{array}$ & 4.07 & 0,88 & $0,713^{* *}$ & $0,840^{* *}$ & $(0,937)$ & \\
Pilot Skills & & & & & & \\
Program & 3,84 & 1,20 & $0,767^{* *}$ & $0,678^{* *}$ & $0,636^{* *}$ & $(0,938)$ \\
Specific & & & & & & \\
Outcomes & & & & &
\end{tabular}

\footnotetext{
Note: Cronbach a coefficients were given on the diagonal in the parentheses $(\mathrm{N}=80)$

$* * \mathrm{p}<0,01$
}

As mentioned above, the objective of the study was to find out if the "Aspects of the Course" dimension was effective on the "Technical Pilot Skills," "Non-Technical Pilot Skills" and "Program Specific Outcomes" dimensions.
A hierarchical regression analysis was conducted for this purpose (Table-7). In the regression analysis, the variables were entered into the model and controlled.

Table 7. Findings of regression analysis concerning the effect of the aspects of the course

\begin{tabular}{cccc}
\hline & Technical & Non-Technical Pilot Skills & Program Specific Outcomes \\
& Pilot Skills & & \\
\cline { 2 - 4 } & $\boldsymbol{\beta}$ & $\boldsymbol{\beta}$ & $\mathbf{B}$ \\
\hline aspects of the course & $0,733^{* * *}$ & $0,713^{* * * *}$ & $0,767^{* * *}$ \\
\hline $\mathbf{F}$ & 90,357 & $89,835^{* * *}$ & $111,705^{* * *}$ \\
\hline$\Delta \mathbf{R}^{2}$ & $0,531^{* * *}$ & 0,503 & 0,58 \\
\hline
\end{tabular}

$* * * \mathrm{p}<0,001$

A hierarchical regression analysis was conducted to see how significantly effective Aspects of the Course was on Technical Pilot Skills, Non-Technical Pilot Skills and Program Specific Outcomes. As shown in Table-8, the aspects of the course were effective on Technical
Pilot Skills $\left(\beta=0.733, \mathrm{p}<0.001 ; \mathrm{F}=90.357 ; \Delta \mathrm{R}^{2}\right.$ $=0.531 ; \mathrm{p}<0.001)$, Non-Technical Pilot Skills $(\beta=$ $\left.0.713, \mathrm{p}<0.001 ; \mathrm{F}=89.835 ; \Delta \mathrm{R}^{2}=0.503 ; \mathrm{p}<0.001\right)$ and Program Specific Outcomes $(\beta=0.767, p$ $\left.<0.001 ; \mathrm{F}=111.705 ; \Delta \mathrm{R}^{2}=0.580 ; \mathrm{p}<0.001\right)$. 
The results of the hierarchical regression agreed with the hypotheses proposed about the aspects of the course, technical pilot skills and non-technical pilot skills.

H1. The course showed a positive and statistically significant relationship with the technical skills of the ab-initio pilots. Thus, hypothesis $H 1$ was confirmed.

H2. The course showed a positive and statistically significant relationship with the nontechnical skills of the ab-initio pilots. Therefore, hypothesis $H 2$ was confirmed.

H3. The course demonstrated a positive and statistically significant relationship with the Program-Specific Outcomes of Professional Flight. Therefore, hypothesis $H 3$ was confirmed.

\subsection{Evaluation of the Students' Knowledge}

In this study, a quiz was used at the beginning of the semester for assessing the knowledge of the students (80) obtained from this new designed course. The same quiz was used at the end of the semester to test if the students really gained an understanding of the course. The implementation of the quiz for the second time allowed us to assess the extent to which the targeted learning outcomes were reached. The mean score of the pretest was found as 68.7. The posttest that was conducted with the students after completing the course had a mean score of 90.7. Furthermore, two midterm examinations and one final examination were given during the regularly scheduled examination period to test what the students learned during the semester. Each student had a higher grade in the posttest in comparison to the pretest. Considering that the pretest and the posttest consisted of different questions, we may argued that learning and awareness were raised in the participants.

\section{Conclusion}

Organizations and individuals should consider failure as an opportunity to obtain lessons for continued improvement, and learning from failure is a good chance for them to introduce measures to minimize the negative consequences of failures and prevent future occurrences. These facts encouraged us to carry out a study on learning from failures in aviation training programs. A brand-new undergraduate elective course was designed by us and launched by the university.

Overall, our research findings revealed that the novice pilots obtained an understanding of causal factors in accidents which might help them avoid repetition of such accidents in the future. There was a great number of benefits derived from the course, and the novice pilots developed intellectual versatility and appealed a wide range of potential employers. All of the 39 novice pilots who graduated from the pilot training department and attended this course were hired by different airlines in Turkey.

It should be noted here that this study significantly contributes to the curricular design of flight training organizations and undergraduate aviation training programs. It is remarkable that lessons learned from this elective course will pave the way for essential safety improvements in flight training of novice pilots. Such safety improvements prevent accidents and incidents and save lives. The effects of the course on the non-technical and technical pilot skills will be evaluated experientially by using a flight training device. Our work along this direction is currently in progress.

Finally, we encourage flight training organizations, airlines and aviation faculties to have a similar course in their curricula or recurrent training programs through this study.

\section{Appendix A. Quiz Questions}

1. State five of the safety issues (probable contributing factors) concerning an accident

2. What is an aviation accident? What is the difference between an aviation accident and incident?

3. What do these following abbreviations stand for?

NTSB :

ICAO:

AFM :

MEL:

ADM: $\quad$ FAA:

FDR: $\quad$ EASA :

CVR: JAA:

4. How can future disasters be averted? Please express your opinion briefly

5. Which ICAO Annex provides the 'Standards and Recommended Practices' to be used for the investigation of aircraft accidents and serious incidents? 


\section{Appendix B. Survey Questions}

Please rate the following aspects of the course.

\begin{tabular}{|l|l|l|l|l|l|}
\hline 1. Assignments were reasonable and appropriate & 1 & 2 & 3 & 4 & 5 \\
\hline 2. Course pace and difficulty were appropriate & 1 & 2 & 3 & 4 & 5 \\
\hline 3. Syllabus accurately described course content and objectives & 1 & 2 & 3 & 4 & 5 \\
\hline 4. Exams and quizzes reflected course content and objectives & 1 & 2 & 3 & 4 & 5 \\
\hline 5. How likely is it that you would recommend this course to a friend? & 1 & 2 & 3 & 4 & 5 \\
\hline
\end{tabular}

Please rate the following aspects of the course to Technical Pilot Skills

\begin{tabular}{|c|c|c|c|c|c|}
\hline 1. The course improved my application of procedures skills. & 1 & 2 & 3 & 4 & 5 \\
\hline 2. The course improved my aircraft and operational knowledge skills. & 1 & 2 & 3 & 4 & 5 \\
\hline $\begin{array}{l}\text { 3. The course improved my use of automatic flight systems (AFS) } \\
\text { skills. }\end{array}$ & 1 & 2 & 3 & 4 & 5 \\
\hline 4. The course improved my Aircraft Handling skills. & 1 & 2 & 3 & 4 & 5 \\
\hline 5. The course improved my aviation knowledge. & 1 & 2 & 3 & 4 & 5 \\
\hline
\end{tabular}

Please rate the following aspects of the course to Non-Technical Pilot Skills

\begin{tabular}{|l|l|l|l|l|l|}
\hline 1. The course improved my communication skills & 1 & 2 & 3 & 4 & 5 \\
\hline 2. The course improved my leadership and teamwork skills & 1 & 2 & 3 & 4 & 5 \\
\hline 3. The course improved my problem solving \& decision-making skills. & 1 & 2 & 3 & 4 & 5 \\
\hline 4. The course improved my situation awareness skills & 1 & 2 & 3 & 4 & 5 \\
\hline 5. The course improved my workload management skills & 1 & 2 & 3 & 4 & 5
\end{tabular}

Please rate the contribution of the course to Professional Flight (PF) Program Specific Outcomes (Aviation Course Outcomes)

\begin{tabular}{|c|c|c|c|c|c|}
\hline 1. Evaluate aviation safety and the impact of human factors on safety. & 1 & 2 & 3 & 4 & 5 \\
\hline $\begin{array}{l}\text { 2. Discuss the impact of meteorology and environmental issues on } \\
\text { aviation operations. }\end{array}$ & 1 & 2 & 3 & 4 & 5 \\
\hline $\begin{array}{l}\text { 3. Discuss the impact of national and international aviation law, } \\
\text { regulations and labor issues on aviation operations. }\end{array}$ & 1 & 2 & 3 & 4 & 5 \\
\hline $\begin{array}{l}\text { 4. Explain the integration of airports, airspace, and air traffic control } \\
\text { in managing the National Airspace System. }\end{array}$ & 1 & 2 & 3 & 4 & 5 \\
\hline $\begin{array}{l}\text { 5. Describe the professional attributes, requirements or } \\
\text { certifications, and planning applicable to aviation careers }\end{array}$ & 1 & 2 & 3 & 4 & 5 \\
\hline
\end{tabular}

(1.Strongly Disagree/2.Disagree/3.Undecided/4.Agree/5.Strongly Agree)

\section{References}

[1] Airbus, "Global Market Forecast-Growing Horizons 2017/2036," 2017.

[2] D. K. Adjekum, "Safety Culture Perceptions in a Collegiate Aviation Program: A Systematic Assessment," 2, 44-56, 2014.

[3] Y. H. Chang, H. H. Yang, and Y. J. Hsiao, "Human risk factors associated with pilots in runway excursions," Accid. Anal. Prev., 94, 227-237, 2016.

[4] CAA, "A strategy for human factors in civil aviation 2014-15," London, 2014.

[5] E. Kim and M. Rhee, "How airlines learn from airline accidents: An empirical study of how attributed errors and performance feedback affect learning from failure," J. Air Transp. Manag., 58, 135143, 2017.

[6] Airbus, "A Statistical Analysis of Commercial Aviation Accidents 19582016," 2017.

[7] ICAO, “A Coordinated , Risk-based Approach to Improving Global Aviation Safety," 2014.

[8] M. Uramatsu, Y. Fujisawa, S. Mizuno, T. Souma, A. Komatsubara, and T. Miki, "Do failures in non-technical skills contribute to fatal medical accidents in Japan? A review of the 2010-2013 national accident reports," BMJ Open, 7, 1-7, 2017.

[9] Flin R; O'Connor P; Crichton M., Safety at 
the sharp end: a guide to non-technical skills. Surrey. England: Ashgate-CRC Press, 2008.

[10] P. Shank, Practice and Feedback for Deeper Learning: 26 evidence-based and easy-to-apply tactics that promote deeper learning and application. Learning Peaks LLC, 2017.

[11] A. Jacobsson, Å. Ek, and R. Akselsson, "Method for evaluating learning from incidents using the idea of 'level of learning," J. Loss Prev. Process Ind., 24, 333-343, 2011.

[12] J. Rasmussen and K. K. J. Vicente, "Coping with Human Errors through System-Design - Implications for Ecological Interface Design," Int. J. Man. Mach. Stud., 31, 517534, 1989.

[13] F. Størseth and R. K. Tinmannsvik, "The critical re-action: Learning from accidents," Saf. Sci., 50, 1977-1982, 2012.

[14] J. Hovden, F. Størseth, and R. K. Tinmannsvik, "Multilevel learning from accidents - Case studies in transport," Saf. Sci., 49, 98-105, 2011.

[15] E. Okstad, E. Jersin, and R. K. Tinmannsvik, "Accident investigation in the Norwegian petroleum industry Common features and future challenges," Saf. Sci., 50, 1408-1414, 2012.

[16] M. A. Sujan, H. Huang, and J. Braithwaite, "Learning from incidents in health care: Critique from a Safety-II perspective," Saf. Sci., 99, 115-121, 2017.

[17] R. Moura, M. Beer, E. Patelli, and J. Lewis, "Learning from major accidents: Graphical representation and analysis of multiattribute events to enhance risk communication," Saf. Sci., 99, 58-70, 2017.

[18] L. Brodie, B. Lyndal, and I. J. Elias, "Heavy vehicle driver fatalities: Learning's from fatal road crash investigations in Victoria," Accid. Anal. Prev., 41, 557-564, 2009.

[19] J. Nixon and G. R. Braithwaite, "What do aircraft accident investigators do and what makes them good at it? Developing a competency framework for investigators using grounded theory," Saf. Sci., 103, 153$161,2017$.

[20] AAIB, "About us," https://www.gov.uk/government/organisati ons/air-accidents-investigationbranch/about. [Accessed: 17-Jun-2018].

[21] CAA, "CAP719 Fundamental Human Factors Concepts," 2002.

[22] NTSB, "A review of flightcrew-involved major accidents of U.S. air carriers, 1978 through 1990," Washington, 1994.

[23] ICAO, "Human Factors Digest: Investigation of Human Factors in Accidents and Incidents," Montreal, 1993.

[24] F. H. Hawkins, Human Factors in Flight, 3rd ed. England: Avebury Technical, 1993.

[25] J. T. Reason, Human Error. Cambridge: Cambridge University Press, 1990.

[26] S. A. Shappell and D. A. Wiegmann, "A Human Error Approach to Accident Investigation: The Taxonomy of Unsafe Operations A Human Error Approach to Accident Investigation: The Taxonomy of Unsafe Operations," Int. J. Aviat. Psychol., 7, 269-291, 1997.

[27] D. A. Wiegman, A Human Error Approach to Aviation Accident Analysis: the Human Factors Analysis and Classification System. Ashgate, Aldershot, UK. Aldershot,UK: Ashgate, 2003.

[28] K. Dönmez and S. Uslu, "İnsan Faktörleri Analiz ve Siniflandirma Sistemi'nin (HFACS) Literatürde Yaygın Kullanımının Değerlendirilmesi-Evaluation of the Widespread Use of Human Factors Analysis and Classification System ( HFACS) in Literature," J. Aviat., 2, 156176, 2018.

[29] Cranfield University, "Cranfield University: Fundamentals of Accident Investigation,"

https://www.cranfield.ac.uk/courses/short/t ransport-systems/fundamentals-ofaccident-investigation. [Accessed: 13-Apr2018].

[30] Embry-Riddle Aeronautical University, "Certificate of Management in Aviation Safety- Aircraft Accident Investigation and Management," https://proed.erau.edu/courses/accidentinvestigation. [Accessed: 13-Apr-2018].

[31] University of Windsor, "Accident Investigation "Araining," http://www1.uwindsor.ca/safety/accidentin vestigation. [Accessed: 13-Apr-2018]. 
[32] NTSB, "NTSB Aicraft Accident Investigation Course," https://www.ntsb.gov/Training_Center/Pag es/AS101_2017.aspx. [Accessed: 13-Apr2018].

[33] FAA, "FAA Aircraft Accident Investigaton International Course Catalog," https://www.academy.jccbi.gov/catalog/int ernational/contents/accidentinvestigation.h tml. [Accessed: 13-Apr-2018].

[34] ICAO, "ICAO Doc 9995 Manual of Evidence-based Training," 2013.

[35] R. Flin et al., "Development of the NOTECHS (non-technical skills) system for assessing pilots' CRM skills," Hum. Factors Aerosp. Saf., 3, 95-117, 2003.

[36] NTSB, "NTSB-Aviation Accident Data Summary-United Airline Flight 232," 1989.

[37] CAA, "Global Fatal Accident Review 2002 to 2011.," 2013.

[38] S. J. Hong, K. S. Lee, E. S. Seol, and S. Young, "Safety perceptions of training pilots based on training institution and experience," J. Air Transp. Manag., 55, 213-221, 2016.

[39] E. Salas, C. S. Burke, C. A. Bowers, K. A. Wilson, and C. Florida, "Team Training in the Skies: Does Crew Resource Management ( CRM ) Training Work?," Hum. Factors, 43, 641-674, 2001.

[40] ICAO, ANNEX 13 Air Accident and Incident Investigation. 2016. 